политика трудового протекционализма, заключающаяся в защите национального рынка труда.Необходимы реализация в полном объеме принципа трипартизма: государство работодатель - работник, обеспечивающего социальную защищенность трудящихся; повышение авторитета и роли в социально-трудовой сфере профсоюзов и органов рабочего самоуправления и самоорганизации - советов трудового коллектива; освоение коллективно-договорных технологий, содержащих организацию переобучения и повышения квалификации, стимулирование профессионального интенсивного труда работников и, наконец, введение социальной ответственности бизнеса через осуществление социальных программ для работников предприятий. Именно такая модель системы социально-трудовых отношений и обеспечит эффективное использование «человеческий капитал» в условиях формирования постиндустриальной экономики в России.

$$
* * *
$$

1. Кузнецова О.Н. Трансформация социально-трудовых отношений на современ-ных промышленных предприятиях: диссертации на соискание ученой степени канд. социол. наук / О.Н. Кузнецова. Ставрополь, 2010.- 163 с.

2. Мелоян В.Г., Савина Ю.В. Формы социально-трудовых отношений на регио-нальном рынке труда [Электронный ресурс] / В.Г. Мелоян, Ю.В. Савина.- URL: https://cyberleninka.ru/article/v/formysotsialno-trudovyh-otnosheniy-na-regionalnom-rynke-truda /

3. Попова Н.В. Система социально-трудовых отношений в рыночной экономике [Электронный ресурс] / Н.В. Попова // Инженерный вестник Дона.- 2012.- № 4 (Ч. 1).- URL: http://www.ivdon.ru/magazine/archive/n4p1y2012/1179

4. Климов Тенденции изменение мира труда в начале XXI века [Электронный ре-сурс] / Климов // Психология труда, инженерная психология и эргономика.- URL: https://studme.org/1376102528023/psihologiya/tendentsii_izmeneniya_mira_truda_nachale_xxi_veka/

\title{
Смирнов М.B.
}

Проблема отчуждения в марксизме: абсолютизация труда и закон стоимости

Череповеикий государственный университет

(Россия, Череповеи)

doi:10.18411/spc-01-10-2018-03

idsp: 000001:spc-01-10-2018-03

\section{Аннотация}

В статье подвергнута анализу проблема отчуждения в марксизме, сводящаяся к метафизической абсолютизации роли труда в общественных процессах; выделены ее основные слабости как на уровне теории, так и на практике.

Ключевые слова: диалектика, отчуждение, марксизм, идеология, труд, техника, закон стоимости.

\section{Abstract}

The article analyzes the problem of alienation in Marxism, which reduces to the metaphysical absolutism of the role of labor in social processes; Its main weaknesses are identified both on the theory level and in practice.

Одной из центральных категорий диалектики является отчуждение, выполняющее функциональную роль в объяснении переходов от стадии к стадии или от состояния к состоянию, связывая их принципом развития и тотальности. Свой широко артикулируемый функционально-онтологический статус отчуждение получило в диалектико-идеалистической системе Гегеля, а широкуюантропологизацию приобрело в трудах младогегельянцев, особенно - в ранних трудах К. Маркса. В «Экономико-философских рукописях 1844 года» и «Немецкой идеологии», отчуждение 
связывается с общим приматом внешнего предметного мира над индивидом, отчуждении его продукта труда и формирования овеществленного сознания.

В т.н. «зрелом» марксизме, лишенном младогегельянского максимализма, эмоциональная сторона дела уходит из его дискурса. Марксизм начинает говорить о формальном отчуждении, как простой констатации социально-экономического факта, абстракции - та же роль, что и у Гегеля в качестве функции перехода и опосредования. В зрелой социально-экономической теории марксизма мы имеем идею отчуждения относительно всего общественно-необходимого труда - простой маркер «могильщика» в наиболее значимом экономическом анализе падения средней нормы прибыли на капитал.

Однако если К. Маркс прямо и не указывает на конкретику социального отчуждения, то косвенных, опосредованных описаний и объяснений этого феномена в «Капитале» предостаточно - когда он ссылается на бедность и нищету рабочих, ужасные условия труда, разрыв в конъюнктуре доходов и т.д. Возможно, привлекать концепцию отчуждения из «Экономико-философских рукописей 1844 г.» не было необходимости, поскольку там она была проработана достаточно исчерпывающе.

Представления об отчужденном состоянии индивида становятся опосредованы марксистским законом стоимости и соответствующей ему абсолютизацией труда в качестве последней инстанции, определяющей антропологию индивида и становление общественных отношений.

Историко-диалектический дискурс западноевропейской философии исторически разворачивался как теория социальной справедливости, разносторонне и антагонистически обосновываемая с позиций материализма и идеализма, эмансипации и иерархии, эксплуатации и служения. Как заметил отечественный исследователь А. А. Глухов: «Даже если диалектическая процедура кажется наукообразной, это значит всего лишь, что нам нужно мыслить науку как теорию справедливости» [1, С. 21].

Сама логика историко-диалектического нарратива, выстраиваемая либо возле становления самосознания, либо возле становления производительных сил и производственных отношений, диктовала ориентацию в границах противоречивой человеческой деятельности (включающей в себя игровой момент, праздность, потребление) именно на труд. Диалектика демонстрировала, как труд формирует интересы и конфликты, перерастающие в определенные антагонизмы групп людей, желающих увеличения собственной или присвоения чужой производительности. В отличие от игры или праздного состояния, труд вводит в сознание человека представление о развитии, о прогрессе, движение которых реализуется засчет прибавочного и эксплуатируемого труда.

Объективность этого реально переживаемого противоречия дает знать о себе в том, что «производительная сила, общественное состояние и сознание - могут и должны вступить в противоречие друг с другом, ибо разделение труда делает возможным - более того: действительным, - что духовная и материальная деятельность, наслаждение и труд, производство и потребление выпадают на долю различных индивидов» [2, С. 31].

Исторический материализм утверждает, что историко-диалектическая доминанта труда в социальной жизни индивида дает знать о себе исторически, следствием чего выступают овеществленные человеческие отношения. Вся критическая историко-диалектическая традиция, восходящая к К. Марксу, выстроена по отношению к абсолютизации значения труда, как в отношениях человека с природой, которые первичны, так и в отношениях человека с человеком. Он привлекает это метафизическое убеждение в анализ политической экономии и сопутствующим ей социальным процессам.

Свои историко-диалектические построения К. Маркс выстраивает вокруг закона стоимости, который утверждает максиму труда в качестве определяющей весь 
последующий процесс и механизм обмена, сущность потребительской, меновой и впоследствии - прибавочной стоимости.

Вместе с тем, что не раз было замечено последующими комментаторами и критиками марксизма, абсолютизация труда как центрального определяющего меновые отношения звена является несостоятельной, что порождает массу противоречий в самой интерпретацией К. Марксом капиталистического способа производства и, как следствие, акцентов социального отчуждения индивидов.

Дискурс труда в марксизме является явно идеологическим, отрицающим какуюлибо первичность помимо труда. Как пишет Л. Дюмон, для него «частная собственность менее реальна чем труд, поскольку является внешним по отношению к человеку» [3, С. 166]. Индивид первичен по отношению к обществу; отношение между человеком и природой труда первично по отношению к отношениям между людьми.

Тот факт, что труд является «человекообразующей» формой деятельности, не говорит о том, что он определяет обмен и производство в «последней инстанции». Были необходимы дедуктивно-метафизические замечания Аристотеля и определяющий его натурализм философии Платона, чтобы в западноевропейской философии закрепилась идея, которую взял на вооружение К. Маркс, о том, что обмен предполагает приравнивание обмениваемых товаров согласно какому-то общему знаменателю. Этим общим оказалась «стоимость». Цепочку дедуктивных заключений К. Маркс выстраивает возле меновой стоимости, опосредуемой уравнением потребительских стоимостей, которые, в свою очередь, восходят к самому феномену стоимости, отражающему факт абстрактного человеческого труда.

Противоречия возникают в тех случаях, когда теория, претендующая на статус науки, открывшей универсальные законы общественной жизни, упускает из виду обмен товаров или продуктов, не вовлеченных в человеческий труд, как, например, даров природы, которые также обладают меновой стоимостью.

Марксистский закон стоимости вступает в противоречие и с самой эмпирической действительностью, поскольку цены производства в ней не соотносятся с затратами рабочего времени на изготовление товара.

Превращение стоимостей в цены производства происходит в результате уравнении норм прибыли и становлении средней нормы прибыли на весь задействованный в общественном производстве капитал. Средняя норма прибыли показывает, что закон стоимости несостоятелен при интерпретации капиталистического производства, поскольку: 1) основную долю в формировании цены продукта и установлении прибыли составляют издержки капитала; 2) эти издержки разнятся в соответствии от состава капитала - переменного или постоянного; 3) колебание цен происходит не возле общего показателя средней нормы прибыли (т.е., якобы, применительно к единой сущности, которая объясняла бы закон стоимости), а возле уровней вложенного в производство капитала и его состава - издержки производства формируют определенный уровень колебания цен, который разительно может отличаться от другого; 4) труд и прибавочная стоимость имеют как количественную, так и качественную сторону, что затрудняет их сведение к одной сущности.

Таким образом, заключает исследователь марксистской политэкономии, экономист Австрийской школы О. Бём-Баверк, «выравнивание прибыли на капитал невозможно, если продукты обмениваются согласно овеществленному в них труду» [4, C. 32]. Это же заставляет усомниться и в статусе «экспроприированной» прибавочной стоимости. Фактически, капиталист в буржуазном рыночном производстве подвергается отчуждению в такой же степени, в рамках своего предприятия, идя на риск и подвергая эксплуатации и износу свое оборудование и материал - средства производства. 
В какой степени вообще можно говорить, что статус буржуазии системно подавляет, эксплуатирует и обирает статус рабочего? Не забывает ли К. Маркс, что сами актанты порой артикулируют совсем иные убеждения относительно социальноэкономической действительности, которая выше общей логики накопления и присвоения? Для того, чтобы утверждать, что над человеком довлеют определенные абстракции необходимо оперировать определенным пониманием человека, его понятием, которое применительно к такого рода анализу может быть только идеологическим. «В данном случае - пишет Л. Дюмон, - наблюдается инверсия отношений нормативной первичности: отношения между людьми - это реальные отношения, и плохо то, что они не осознаются косвенным путем, через посредников, выраженных в вещах, т.е. в товарах, обладающих меновой стоимостью» [3, С. 188].

Марксистский дискурс приводит два рода утверждения о господстве абстракций над человеком - в первом случае, это касается моральной оценки и негативной природы определенных абстрактных вещей, вроде денег, которые извращают природу человека; во втором, это господство объективное, связанное с продуктами труда рабочего, которые от него отчуждаются на товарно-капиталистическом производстве. При этом забывается, что капиталист также в процессе производства отчуждает свой капитал, включая его в игру спроса и предложения, свои средства производства; рабочий же (впрочем, как и капиталист, поскольку его статус не закреплен сословно), за отсутствием законодательных ограничений по типу сословных, имеет право выбора - продать свою рабочую силу работодателю, представляющему фабричное производство, инновационно-технологическое предприятие или мобильное, сезонное производство определенного вида товара, либо и вовсе приобрести средства производства и стать независимым рыночным производителем.

Когда категория отчуждения приобретает столь общий статус, становится сложно говорить на ее языке о частностях. Отчуждение одной переменной в уравнении имело бы смысл, однако констатация отчуждения всего уравнения переводится на язык формальной логики, теряя связь с логикой неформальной, социальной. Относительно же языка диалектики, как мы могли убедиться, ничего определенного вообще сказать невозможно - нужна конкретная ситуация и конкретная операционалистская интерпретация, дающая смысл частностям. Проблема в том, что в нормативной социальной реальности, актанты апеллируют лишь к частностям.

Примечательно то, что во всех указанных случаях отчуждение продукта труда от рабочего хоть и нормативно-предполагается, но все же не является самоочевидным для этого необходимо каждый раз учитывать структуру и состав капитала, условия и цели его фигурирования на рынке товаров, политику его обладателя, которая, подчас, обладает более серьезной основательностью в достижении цели, чем степень его стремления к извлечению прибыли.

Противоречие закона стоимости возникает и с ожиданиями от исторического изменения и перерастания капиталистической формации в социалистическую, поскольку любое производство и отчуждение индивида связаны, а человек - это всегда сознательная деятельность, или «производство».

Поразительным образом, если присмотреться, историческая роль техники у М. Хайдеггера в мире экзистенциально-онтологическом соответствует тем же интерпретациям мира социально-экономического с позиции закона стоимости. Однако, при этом, немецкий экзистенциалист пришел к совершенно иным, нежели Гегель и К. Маркс, выводам.

Диктат технологического производства М. Хайдеггер принимал в качестве тезиса, как судьбу. Здесь он вводит термин «постав», как некий «вызов, который сосредотачивает человека на поставлении всего, что выходит из потаенности, в качестве состоящего-в-наличии» [5, С. 229]. 
Судьба человечества - постав, как определенный способ производящедобывающего раскрытия потаенности. Этому раскрытию подвергается все сущее, включая человека. Человеческая история - история постава, который формирует человеческое сознание, производство, технику и, как следствие, ее исторический диктат.

Состоящая-в-наличии действительность обесценивается в той мере, в которой она раскрыта человеческим потребностям и поставлена на обслуживание их интересам. В этом и состоит опасность раскрытия. «Коль скоро непотаенное захватывает человека даже и не как объект, пред-стоящий человеку, а уже исключительно как состоящее-вналичии, человек среди распространившегося материала становится просто представителем этой наличности - он ходит по крайней кромке пропасти, а именно того падения, когда он сам себя будет воспринимать уже просто как нечто состоящее в наличии» [5, С. 233].

М. Хайдеггер опосредует становление и деятельность человека не телеологией некой реальности, исторически предопределенной и довлеющей над ним, но самим человеческим действием, его ответственностью. Кроме того, именно историкодиалектический дискурс становится самой что ни на есть техникой, поставом, стремящимся уничтожить, по выражению Л. Дюмона, любые условности, через обращение к идее и ценности «с целью обозначить, оценить и ввести некую среднюю огрубленную характеристику жизни».

Диалектика и отчуждение, таким образом, должны основываться на расширении и привлечении новых теоретических посредников, укреплении обратной связи с самими актантами, их нормативными суждениями и убеждениями - даже в случае обращении к логике, как артикуляции общих категориальных форм. Акторно-сетевое восприятие и объяснение социальных процессов и противоречий сегодня обладает большей легитимностью в сравнении с крупными метафизическими системами и метанарративами, абсолютизирующими одни аспекты реальности и игнорирующими другие.

$$
* * *
$$

1. Глухов А. А. Политический смысл диалектики // Вестник РХГА, 2013. - Т. 10. - № 3. - С. 19 - 28.

2. Маркс К., Энгельс Ф. Немецкая идеология / К. Маркс, Ф. Энгельс. Собр. соч. изд. 2. - М.: Издательство политической литературы, 1955. - Т. 3. - С. 7 - 544.

3. Дюмон Л. HomoAequalis. Генезис и расцвет экономической идеологии / Под общ.ред. канд. пол. н. В. И. Даниленко. - M.: NOTA BENE, 2000. - 239 с.

4. Бём-Баверк О. Критика теории Маркса / Сост. А. В. Куряев. - М., Челябинск: Социум, 2002. - 283 с.

5. Хайдеггер М. Вопрос о технике // Время и бытие: Статьи и выступления / Пер. с нем. В. В. Бибихина. - М.: Республика, 1993. - С. $221-238$.

\section{Токарев Д.А.}

\section{Атрибутивность гедонистического варианта страдания}

Омский институт водного транспорта - филиал ФГБОУ ВО «СГУВТ»

(Россия, Омск)

doi:10.18411/spc-01-10-2018-04

idsp: 000001:spc-01-10-2018-04

\section{Abstract}

Man is suffering from the point of view of different philosophy ages is considered in this article. The description for features of hedonistic version of the reasons, manifestations and possibilities of suffering overcoming is given. The negative sides of hedonistic approach to suffering are defined. 